In December 2000, Shehadeh's mother, as a member of the Jerusalem choir's annual Christmas concert, summed up what he and all Palestinians want. Unable to go to Jerusalem, the choir sang at the Qalandia checkpoint, and his mother stood in the rain carrying a placard that stated simply: "End the occupation now. Israelis go home" (p. 152).

The book by Oikonomides shows us the poverty and deprivation of a segment of the Palestinian population that Shehadeh does not highlight. As a young woman with a Greek surname, she became actively engaged with the Palestine solidarity movement in France. She went to Palestine in October 2000, initially to work and live in the Qalandia refugee camp, a location that enabled her to observe the class divisions of Palestinian society. She notes that the director of a cooperative designed to help the poor does not live in the camp and displays the arrogance of a middle-class Palestinian who has disdain for refugees who have become dependent on assistance (p. 29). In contrast is Um Sleiman, a camp resident who cleans the cooperative, is religious and veiled, but a great cook and hospitable. She adopts Oikonomides, a European outsider who thus is in a better position to see the other Palestine. Oikonomides observes that Um Sleiman had not gone beyond elementary education, but she learned Hebrew and other things on her own. And she manages to work, care for eleven siblings, and keep a positive demeanor despite the hardships of occupation. More details about Um Sleiman and others like her would have enhanced the book. Missing, too, are details about the author's own work during her three years in Palestine.

Oikonomides displays a good sense of humor and irony, as she tries to explain what occupation entails. In "The Colors of Discrimination," she dazzles her reader with the various color-coded license plates and identity (ID) cards. The holders of blue cards can enter Jerusalem, but the holders of green cards are not allowed to leave the West Bank. The color game can become surreal. She describes a house in Qalandia, where the balcony is physically located in Jerusalem, and the bedrooms are in the West Bank. With much irony she says, "don't ask me the color of the identity cards of this houses' inhabitants" (p. 59). The rules are simple: Green and orange ID cards with green license plates mean "do not pass." Others with green IDs and work permits mean "pass but on foot." Blue cards and yellow license plates mean "pass" (welcome to Israel), etc. The message is clear: the color of racism (p. 60).

After four months in Qalandia, Oikonomides moved to Bayt Hanina, and a few months later, relocated to Ramallah, where she remained until October 2003. Oikonomides introduces her French readers to the meaning of checkpoints, the humiliation that Palestinians experience on a daily basis, and the absurdity of the Israeli regime of occupation. She provides hand-drawn illustrations of checkpoints, maps that identify settlements (colonies), and sketches of settler roads that Bantustanize the West Bank. She introduces simple and poor Palestinians and focuses on the young (shebab). And like Shehadeh, she does not shy away from criticizing the culture of arms that prevails among Palestinians.

\section{REFUGEES' PREDICAMENT}

The Palestinian Impasse in Lebanon: The Politics of Refugee Integration, by Simon Haddad. Foreword by Hilal Khashan. Brighton, UK and Portland, OR: Sussex Academic Press, 2003. $x+148$ pages. Appendices to p. 161. Select Bibliography to p. 170. Index to p. 179 . $\$ 65.00$ cloth.

Palestinian Refugees in LebanonWhere to Belong? by Dorothée Klaus. Berlin: Klaus Schwarz Verlag, 2003. 176 pages. Bibliography to p. 199. Index to p. 205. 25 euros paper.

\section{Reviewed by Laleh Kbalili}

In the aftermath of the Lebanese civil war (1975-1991) and in reaction against refugee settlement schemes that first were fielded during the 1992 Madrid talks, the Lebanese government increasingly and drastically has curtailed Palestinian refugees' civil rights. The aim of the draconian limits on Palestinian employment, property ownership, and university education has been an open secret throughout: The Lebanese state wishes to "encourage" Palestinian refugees in Lebanon to emigrate, so as to reduce the numbers of

Laleh Khalili is a Ph.D. candidate in political science at Columbia University. The title of her soon-to-be-completed doctoral dissertation is Citizens of an Unborn Kingdom: Stateless Palestinian Refugees and Contentious Commemoration. 
possible refugees settling in Lebanon at a future date. Conventional wisdom holds that these policies have arisen because the great majority of the Lebanese do not want Palestinian refugees settled in their midst. The two volumes reviewed here support this view, although the authors use differing - though complementary-methods for arriving at their conclusions.

Haddad, an associate professor of political science at the Notre Dame University in Lebanon, utilizes survey questions to gauge the attitude of the Lebanese toward Palestinian refugees and their possible settlement in Lebanon. He also surveys Palestinian refugees about their opinions of possible Palestinian statehood and settlement in Lebanon or further afield. His pool of respondents includes 273 Palestinians who were "interviewed at and outside the camps" (p. 79) and 1,073 Lebanese citizens. The Lebanese respondents are mostly 18-35 years old (72 percent), male (64 percent), college educated (58 percent), and "people with professional and managerial occupations" (p. 77). Although Haddad has collected data on the respondents' age, class, and gender, his primary basis of measurement and comparison is religious identity. However, even in this small sample, Christians are overrepresented: Whereas population estimates put the percentage of Lebanese Christians at or below 30 percent, nearly half of Haddad's respondents (48 percent) are Christians. By contrast, the Shi'a, the Sunni, and the Druze comprise respectively 27,18 , and 7 percent of all respondents (p. 77). The author does not provide a similar breakdown by age, gender, class, or religion for the Palestinian respondents (although the questionnaires indicate that he collected this data), and nor do we know what percentage are camp residents.

Prior to the analysis of the survey results in chapters seven through eleven, Haddad outlines the historical and social background of Palestinian refugees' presence in Lebanon. The first four chapters include a review of the strategies of regional parties to the Arab-Israeli conflict, a brief overview of the Palestinian exodus from Israel in 1948, an assessment of the Palestinians' role in the Lebanese civil war (in chapter three, Haddad claims that the civil war was primarily between Palestinian guerrillas and local militias), and the obstacles to Palestinian integration and resettlement. Haddad also attempts to ground his analysis in theory by drawing comparisons with and using conceptual tools from research on immigration to North America and Australia. The conclusions he draws from his survey results confirm his original hypothesis that most Lebanese do not want to see Palestinian refugees settled in their midst, blame the Palestinians for the civil war, and do not desire their integration or assimilation into the Lebanese society. (His Sunni and Druze respondents are far less adamant than other sectarian groups in their hostility toward and distrust of Palestinians.) While this conclusion in itself is unsurprising, Haddad also interestingly argues that this hostility is a result of low interaction between the Lebanese and Palestinian respondents, and that "the higher the respondents' frequency of communication, the more they feel closer to Palestinians" (p. 122).

The second volume is based on the author's doctoral thesis, and it uses ethnography to explore the attitudes of Lebanese and Palestinians toward one another. Klaus conducted 180 in-depth interviews and held even more informal conversations with Palestinian and Lebanese respondents belonging to different backgrounds. Although she does not provide an overall breakdown of her correspondents' age, gender, class, or confessional belonging, when quoting them in the text-which she does extensivelyshe identifies them by all of those factors, while allowing them to remain anonymous. In her introduction, she states her aim as understanding "the sources of both continuous stalemate and coexistence" (p. 8), as well as focusing on Palestinians who live outside the camps (p. 6). However, the book seems to cover a vast and sometimes unwieldy range of anthropological themes (such as statelessness, kinship, the honor code, fear and trauma, and unsettled populations, among others), and most of the Palestinians quoted seem to be camp residents.

One of the strengths of Klaus's book is the excellent range of "voices" recorded throughout. She liberally quotes her respondents in order to provide anecdotal support for her thematic arguments, and the range of opinions and attitudes she conveys through these direct quotes is illuminating and interesting. Klaus dedicates nearly half the book to an historical summary of the Palestinian predicament in Lebanon. Although the respondents' anecdotes are colored by their present concerns and prejudices and may not represent their political positions in the 1970 s and 1980s, nevertheless, these chapters are fascinating to read, and by providing 
the Lebanese viewpoint of those years, complement Rosemary Sayigh's groundbreaking From Peasants to Revolutionaries (London: Zed Books, 1979) and Too Many Enemies (London: Zed Books, 1994). The latter half of chapter six and the whole of chapter seven, where the Palestinian respondents voice doubts about their future, their identity, and their relation with their hosts, are among the more poignant and interesting sections in the volume, as they show the complexity of attitudes present in a particular social group. Similarly, the direct quotations by Klaus's Lebanese respondents show that their opinions toward Palestinians are not monolithic and can range from sympathetic (p. 96) to vitriolic (pp. 94-95) to downright bigoted (p. 97).

A fundamental premise in both books is that the confessional identities of the actors is their primary categorical identity and that it determines their attitudes and opinions, although Klaus's research-implicitly-shows that class is a significant factor in delineating attitudes. Both authors assume sectarian allegiances as monolithic, internally coherent, and the primary motivator of politics. In some ways, the readers of both books are expected to know the internal politics of Lebanon and to understand the euphemisms that are intended to describe someone's politics through naming his or her religion. Thus, Klaus's identification of a respondent as "Maronite technician, Mount Lebanon area" (p. 97) is supposed to evoke in the reader historical knowledge of the role of Mount Lebanon's Maronites in the civil war and it replaces a discussion of the politics in which this person is engaged. Haddad's similarly unproblematic use of confessional categories as euphemisms for political positions transforms all Maronites into implacable foes of Palestinians, and all Sunnis as stalwart supporters. That the voices of individual Sunnis recorded in Klaus's volume may show antipathy toward the Palestinians or that more than a few Maronites in her book voice their sympathy toward Palestinians undermines the authors' unquestioned privileging of confessional belonging. Their prioritization of sectarian allegiances ignores political relations within and across sectarian groups.

Aside from this serious problem, both volumes could have benefited from a firmer editorial hand. Klaus works with such fascinating material that she sometimes loses sight of her central argument and covers ground that is only tangential to her orig- inal focus. For example, her discussion of pre-1948 life in Palestine (pp. 135-42) has little bearing on her argument. In Haddad's volume, more attention should have been paid to fact checking, to prevent glaring errors such as describing Hamas as "a splinter group of Osbat al-Ansar" (p. 81 n. 5) or stating that Lebanon "has some of the fewest resources and wealth [sic]" in the Middle East (p. 45). Haddad's inconsistent and incorrect spelling of names and confusing use of honorific titles in both the text and the bibliography are also problematic. For example, Rosemary Sayigh's last name is rendered as "Sayyigh" in the text and the bibliography, and political scientist Farid al-Khazen's name is preceded with the use of the honorific "Sheikh" (p. 32), which can bemuse the unfamiliar reader. More significantly, Haddad uses quoted material ahistorically; for example, describing a present-day situation by using a quote from a 1984 article by Rashid Khalidi (p. 42 and p. 48 n. 7), or utilizing a Kata'ib party document from 1999 to explain Maronite attitudes circa the 1970s (p. $38 \mathrm{n}$. 16 and p. 32). The absence of details and the proliferation of euphemized discussion lead Haddad either to make sweeping generalizations without further explanation-"Any [demographic] imbalance would have a major political, social, economic and security impact" (p. 47)-or to assert facts without documentary support. For example, in a footnote, he reports that the number of refugees registered with UNRWA is nearly 400,000 , half residing in the camps, but "the researcher was told [by whom?] that the real number [of camp residents or all refugees?] did not exceed 130,000" (p. 80). More mundanely, the English used in both volumes is sometimes awkward and occasionally grammatically incorrect.

Despite these shortcomings, some of which are more than minor, these books provide rare empirical snapshots of LebanesePalestinian relationships at the beginning of the twenty-first century. These can be valuable to policymakers and researchers discussing the predicament of Palestinian refugees and trying to understand the social attitudes of their Lebanese hosts.

\section{CONVENTIONAL ZIONISM}

The Invention of a Nation: Zionist Thought and the Making of Modern Israel, by Alain Dieckhoff. New York: Columbia University Press, 2003. 